\title{
Inflammation in atherosclerotic cardiovascular disease
}

\section{[version 1; peer review: 4 approved]}

\author{
Prediman K. Shah (11), Dalgisio Lecis ${ }^{1,2}$ \\ ${ }^{1}$ Helga and Walter Oppenheimer Atherosclerosis Research Center, Smidt Heart Institute, Cedars Sinai Medical Center, Los Angeles, \\ CA, USA \\ ${ }^{2}$ Department of Cardiovascular Medicine, "Tor Vergata" University of Rome, Rome, Italy
}

V1 First published: 09 Aug 2019, 8(F1000 Faculty Rev):1402

https://doi.org/10.12688/f1000research.18901.1

Latest published: 09 Aug 2019, 8(F1000 Faculty Rev):1402

https://doi.org/10.12688/f1000research.18901.1

\section{Abstract}

Atherosclerotic cardiovascular disease is a leading cause of death and morbidity globally. Over the past several years, arterial inflammation has been implicated in the pathophysiology of athero-thrombosis, substantially confirming what pathologist Rudolf Virchow had observed in the 19th century. Lipid lowering, lifestyle changes, and modification of other risk factors have reduced cardiovascular complications of athero-thrombosis, but a substantial residual risk remains. In view of the pathogenic role of inflammation in atherothrombosis, directly targeting inflammation has emerged as an additional potential therapeutic option; and some early promising results have been suggested by the Canakinumab Anti-inflammatory Thrombosis Outcome Study (CANTOS), in which canakinumab, a fully human monoclonal antibody targeting the pro-inflammatory and proatherogenic cytokine interleukin 1 beta, was shown to reduce cardiovascular events.

\section{Keywords}

Atherosclerosis, Inflammation, thrombosis

\section{Open Peer Review}

\section{Approval Status}

1

2

version 1

09 Aug 2019

Faculty Reviews are review articles written by the prestigious Members of Faculty Opinions. The articles are commissioned and peer reviewed before publication to ensure that the final, published version is comprehensive and accessible. The reviewers who approved the final version are listed with their names and affiliations.

1. Jan Nilsson, Lund University, Lund, Sweden

2. Avijit Lahiri, British Cardiac Research Trust, Prince Albert Road, UK

3. Petri T Kovanen, Wihuri Research Institute, Helsinki, Finland

4. Magnus Bäck, Karolinska University Hospital, Stockholm, Sweden

Any comments on the article can be found at the end of the article. 
Corresponding author: Prediman K. Shah (shahp@cshs.org)

Author roles: Shah PK: Conceptualization, Data Curation, Formal Analysis, Investigation, Methodology, Writing - Original Draft Preparation, Writing - Review \& Editing; Lecis D: Writing - Review \& Editing

Competing interests: PKS is a co-inventor of apo B-100 related peptide vaccines and is on the scientific board of Cardiovax Inc. Grant information: The author(s) declared that no grants were involved in supporting this work.

Copyright: $\odot 2019$ Shah PK and Lecis D. This is an open access article distributed under the terms of the Creative Commons Attribution License, which permits unrestricted use, distribution, and reproduction in any medium, provided the original work is properly cited.

How to cite this article: Shah PK and Lecis D. Inflammation in atherosclerotic cardiovascular disease [version 1; peer review: 4 approved] F1000Research 2019, 8(F1000 Faculty Rev):1402 https://doi.org/10.12688/f1000research.18901.1

First published: 09 Aug 2019, 8(F1000 Faculty Rev):1402 https://doi.org/10.12688/f1000research.18901.1 


\section{Introduction}

Cardiovascular disease from atherosclerosis manifests as acute and chronic ischemic syndromes such as acute coronary syndromes, angina pectoris, claudication, ischemic strokes, congestive heart failure, and sudden and non-sudden cardiac death ${ }^{1-4}$ Atherosclerosis consists of build-up of plaque inside the intima of medium and large arteries, leading to chronic luminal narrowing or disruption of the plaque surface (plaque rupture or superficial erosion) with superimposed thrombosis and a subacute or acute luminal compromise. Most of the acute and lifethreatening manifestations of atherosclerosis result from plaque disruption and thrombosis ${ }^{1-4}$.

\section{Pathophysiology of atherosclerosis}

Atherosclerotic plaques contain a variable mix of lipids, smooth muscle cells, extracellular matrix, calcium, and components of the immune system (both from innate and adaptive immunity) such as macrophages, dendritic cells, mast cells, natural killer cells, and $\mathrm{T}$ cells. In addition, increased plaque neovascularization and intraplaque hemorrhage are features of atherosclerotic plaques. Although the precise mechanism of athero-thrombosis remains incompletely understood, a number of risk factors that increase the likelihood of atherogenesis have been identified: these include dyslipidemia with elevated apolipoprotein B (apoB) 100-containing lipoproteins, low levels of high-density lipoprotein (HDL), hypertension, diabetes, smoking, central obesity and metabolic syndrome, advanced age, menopause, genetic factors and family history of premature coronary disease, chronic immune-inflammatory conditions (such as psoriasis, rheumatoid arthritis [RA], systemic lupus erythematosus, HIV, and Kawasaki's syndrome), chronic infections, and radiation exposure ${ }^{1-5}$. Cardiovascular disease is now recognized as a major cause of premature mortality among patients with autoimmune chronic inflammatory conditions, and there is an urgent need to identify those who are at risk of cardiovascular ischemic events in order to optimize prevention and therapeutic intervention ${ }^{6}$. In this regard, several clinical trials showed that methotrexate use is associated with a reduced risk of cardiovascular events in patients with RA. This suggests that reducing the inflammation in RA by using methotrexate not only improves disease-specific outcomes but also may reduce collateral damage such as atherosclerosis ${ }^{7,8}$.

\section{Key role of lipids in atherogenesis}

It is generally agreed that lipids play a key role in the initiation of atherosclerosis. Experimental observations have suggested that one of the earliest events in atherogenesis is the entry of atherogenic (apoB 100-containing) lipoproteins into the sub-endothelial space, where they interact with extracellular matrix components, leading to trapping of lipoproteins with subsequent aggregation and oxidative modification and then to generation of pro-inflammatory lipids ${ }^{9,10}$. These pro-inflammatory lipids lead to endothelial dysfunction manifesting with increased adhesivity of endothelium to circulating mononuclear cells which then are recruited into the sub-endothelium aided by the local production of inflammatory cytokines. Monocytes in the sub-endothelium mature into macrophages expressing scavenger receptors through which the lipids are engulfed, turning monocyte-derived macrophages into foam cells. Some foam cells are also derived from vascular smooth muscle cells. Monocytemacrophages in the lesion secrete mediators that also recruit smooth muscle cells from the media; these smooth muscle cells migrate, proliferate, and secrete matrix proteins, contributing to build-up of plaque; some macrophages and dendritic cells present neoantigens to the $\mathrm{T}$ cells, creating a pro-inflammatory adaptive immune response that perpetuates inflammation in the plaque ${ }^{1}$.

\section{Critical role of inflammation in hyperlipidemia- induced atherogenesis}

Experimental studies and many clinical observations have shown that hyperlipidemia is essential but not sufficient to produce atherosclerosis unless there is inflammation as well. Inflammation was, in fact, implicated in atherosclerosis by Virchow as far back as in $1858^{11}$. Many cytokines and chemokines are involved in the development and progression of the atherosclerotic plaque. Some of them, such as colony-stimulating factor-1 (CSF-1) and monocyte chemoattractant protein-1 (MCP-1), whose partial or complete deletion dramatically reduces atherosclerosis in murine models despite severe hyperlipidemia, are important in the initial phases of plaque formation ${ }^{12}$. Hyperlipidemia activates innate immunity by activating Toll-like receptor 2 (TLR-2) and TLR-4 pathways, leading to activation of inflammatory and pro-atherogenic genes in macrophages and endothelial cells ${ }^{12}$. Disruption of lipid-induced innate immune signaling reduces atherosclerosis in hyperlipidemic murine models ${ }^{12}$. Given the multifactorial nature of cardiovascular disease and the complexity of the inflammation pathways involved in atherosclerotic plaque development (as shown in Figure 1), the implications of findings in hyperlipidemic mice have to be carefully assessed when considering humans. In addition to apoB 100-containing lipoproteins, HDL may become pro-inflammatory and pro-atherogenic when it undergoes chemical modification by macrophage-derived myeloperoxidase or mast cell-derived proteases through acquisition of pro-inflammatory mediators (such as serum amyloid A and symmetrical dimethyl arginine) or loss of anti-inflammatory mediators (such as clusterin, paraoxonase, and apoA-1), creating a dysfunctional form of HDL which promotes atherosclerosis ${ }^{13}$. Furthermore, mast cell-derived neutral proteases neutralize some of the critical anti-atherogenic functions of HDL. Thus, they degrade the pre-beta-HDL fraction, thereby blocking the ABCA1dependent cholesterol efflux from foam cells ${ }^{14}$. Moreover, the anti-inflammatory functions of apoA-1 on endothelial cells are lost upon its C-terminal cleavage by the human mast cell neutral protease chymase ${ }^{15}$.

Thus, a large body of evidence implicates inflammation in the initiation and progression of atherosclerosis ${ }^{1-5,12}$. Inflammation has also been implicated in outward remodeling that occurs with plaque formation, intraplaque neovascularization and plaque hemorrhage, matrix depletion with thinning of the fibrous cap through increased matrix proteolysis mediated by matrixdegrading enzymes, and eventually disruption of the fibrous cap leading to thrombosis ${ }^{1-5,12}$. Plaque thrombogenicity has also been attributed to macrophage-derived tissue factor within the plaque ${ }^{1-5,12}$. Thus, inflammation plays an important role at multiple steps in the evolution of athero-thrombosis. 


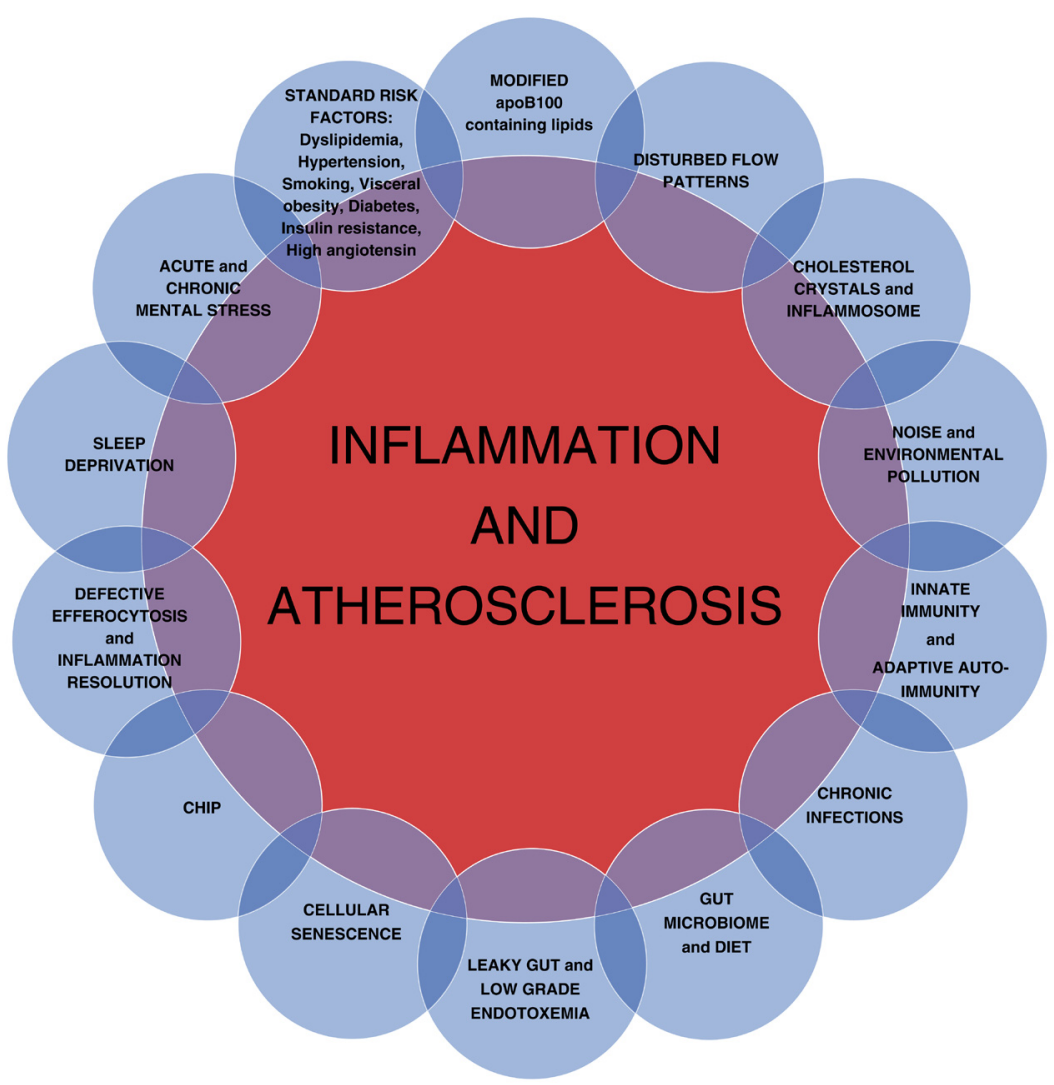

Figure 1. Different pathways for inflammation in athrosclerosis are depicted in this figure. (CHIP, clonal hematopoetic mutations of indeterminate potential).

\section{Do other factors contribute to inflammation in atherosclerosis?}

Local shear stress and flow dynamics

Atherosclerotic plaques tend to preferentially form at sites of low or oscillating shear stress, such as branch points and curvatures where flow patterns are disturbed; these disturbed flow patterns appear to promote entry of atherogenic lipoproteins by increasing their residence time; in addition, such disturbed flows promote a pro-inflammatory endothelial phenotype that is orchestrated by flow-sensitive transcription factors such as KLF2; inhibition of KLF2 by low shear stress promotes a proinflammatory phenotype contributing to atherogenesis and plaque inflammation ${ }^{16}$. Murine studies have shown that athero-prone sites of normolipidemic mouse aorta contain cellular components priming these sites for enhanced inflammatory responses ${ }^{17}$.

\section{Cholesterol crystals and inflammasome activation}

Cholesterol crystals, frequently present in atherosclerotic plaques, can activate the NLRP3 inflammasome pathway to induce secretion of pro-inflammatory and atherogenic cytokines like interleukin 1 beta (IL-1 $\beta$ ) and IL-18 ${ }^{18-22}$. Activation of NLRP3 inflammasome requires a priming signal which can be provided by neutrophil-derived extracellular traps and by oxidized lipids followed by the second signal provided by cholesterol crystals $^{19}$. Mitochondrial damage and dysfunction can also play important roles in activating NLRP3 inflammasome ${ }^{21,22}$.

\section{Integrated stress response, inflammation, and} atherosclerosis

Dyslipidemia, especially exposure to saturated fatty acids, induces endoplasmic reticulum stress, mitochondrial oxidative stress, and elF2 alpha phosphorylation which hyperactivates an integrated stress response (ISR), which in turn activates a local and systemic inflammatory response through activation of NLRP3 inflammasome: this process contributes to atherogenesis since inhibition of ISR at different nodes reduces atherosclerosis in hyperlipidemic murine models ${ }^{22}$. Small-molecule ISR inhibitors could emerge as important anti-inflammatory agents for atherosclerosis and other chronic inflammatory conditions ${ }^{22,23}$.

\section{Visceral obesity, insulin resistance, and type II diabetes} mellitus

Several studies have shown that visceral adiposity is associated with organ-specific inflammation involving the adipose tissue, liver, pancreas, and arterial wall; visceral adipose tissue of diet-induced obese mice was demonstrated to be rich in $\mathrm{T}$ cells secreting interferon gamma (IFN- $\gamma$ ) at higher levels than lean controls. This inflammation is associated with insulin 
resistance and metabolic syndrome, eventually contributing to the development of type II diabetes mellitus ${ }^{24-28}$. Diabetesassociated dyslipidemia and pro-inflammatory state contribute to enhanced atherogenesis observed with diabetes ${ }^{24-28}$.

\section{Smoking and environmental pollution}

Active smoking and passive exposure to smoking are associated with increased atherogenesis and risk of acute vaso-occlusive cardiovascular events mediated in part by pro-inflammatory and pro-thrombotic effects of smoke exposure ${ }^{29}$, which are associated in part with perturbations on lipid metabolism ${ }^{30}$. Similarly, environmental pollutants may induce inflammation, enhancing risk of cardiovascular disease ${ }^{29}$. The underlying mechanism in both cases may be due to the increased production of reactive oxygen species (ROS) exceeding the endogenous antioxidant capacity associated with an increase in the markers of inflammation ${ }^{31,32}$.

\section{Hypertension and inflammation}

Recent studies have implicated oxidative stress and innate and adaptive immunity in hypertension and hypertension-related end organ damage. Angiotensin II, salt retention, or increased mineralocorticoid activity activates innate immunity that precipitates or aggravates hypertension ${ }^{33}$. These hypertensive stimuli also induce oxidative stress in antigen-presenting cells which lead to neoantigen formation ${ }^{33}$. These neoantigens in turn lead to an adaptive immune response which can further damage end organs such as the kidney ${ }^{33}$. Several experimental studies have implicated $\mathrm{T}$ helper 17 (Th17) cells and their cytokines in inflammation in hypertension, and IL-10 has a counterbalancing role by producing regulatory $\mathrm{T}$ (Treg) cells $\mathrm{s}^{33}$.

\section{Adaptive autoimmunity and inflammation in atherosclerosis}

An adaptive immune response to autoantigens, both humoral and cell-mediated, exists in animal models of atherosclerosis and in human subjects ${ }^{1,34,35}$. T-cell activation occurs upon presentation of the antigen in the setting of an inflammatory state, resulting in clonal proliferation and in the differentiation of $\mathrm{CD}^{+} \mathrm{T}$ cells to Th1, Th2, or Th17 phenotype, depending on the cytokines secreted by the antigen-presenting cells ${ }^{1,34,35}$. Both a proatherogenic inflammatory immune response mediated by Th1 and possibly Th17 and B-cell subsets and an athero-protective antiinflammatory immune response mediated by Treg cells and B1 cells have been shown to exist and modulate atherosclerosis ${ }^{1,34,35}$. Autoantigens that have been identified include antigens derived from both the protein and lipid components of apoB 100containing lipoproteins, heat shock protein 60 (HSP 60), and beta glycoprotein ${ }^{1,34,35}$. These observations have led to the concept of immunomodulatory therapies for atherosclerosis, which are being developed in various laboratories ${ }^{34,35}$.

\section{Infections, atherosclerosis, and cardiovascular events}

Several studies have implicated infections to either atherogenesis or precipitation of acute cardiovascular events ${ }^{5,36,37}$. These infections include influenza, gingivitis, urinary tract infections, skin infections, HIV, pneumonia, and Helicobacter pylori infections $s^{5,36,37}$. The link between infection and atherosclerosis has been attributed to direct infection of the vessel wall (Chlamydia pneumoniae), indirect effects involving molecular mimicry, or systemic pro-inflammatory effects ${ }^{5,37}$. However, a number of large-scale randomized clinical trials targeting $C$. pneumoniae with antibiotics failed to reduce cardiovascular events 5 . On the other hand, influenza vaccination has been shown to reduce cardiovascular events in a limited number of randomized clinical trials and in many observational studies ${ }^{5}$. The cardioprotective effects of pneumococcal vaccines have not been as persuasively demonstrated ${ }^{5}$.

\section{Diet and gut microbe interaction}

In recent years, gut microflora has been implicated in the pathogenesis of a number of diseases, including obesity, diabetes, hypertension, atherosclerosis-thrombosis, and neurodegenerative disease $^{38}$. Several studies have suggested that certain dietary constituents such as phosphatidylcholine, choline, and carnitine are acted upon by enzyme trimethylamine lyase (TMA lyase) produced by gut microbes such as Clostridia, Shigella, Proteus, and Aerobacter to generate TMA which is converted into trimethylamine oxide (TMAO) by hepatic flavin monooxygenases. TMAO enhances foam cell formation by upregulating macrophage scavenger receptors which may contribute to its pro-atherogenic effects ${ }^{38}$. In addition, TMAO enhances platelet activity and predisposes patients to thrombosis ${ }^{38}$.

In human subjects, circulating TMAO levels correlate with the presence of coronary artery disease and the future risk of athero-thrombotic cardiovascular events ${ }^{38}$. TMAO also has been shown to contribute to enhanced atherogenesis in murine models and enhanced platelet aggregation ${ }^{38}$. In murine models, antibiotics directed at gut microflora reduce atherogenesis ${ }^{38}$. Inhibition of TMA-generating microbial enzymes by dimethylbetane also reduces murine atherosclerosis ${ }^{38}$. Consumption of a Mediterranean-type diet is also associated with lower circulating levels of $\mathrm{TMAO}^{38}$ and this may account for the antiinflammatory and health-promoting effects of a Mediterranean diet. Recently developed, non-toxic potent inhibitors of gut microbial TMA lyase (halomethylcholines) were shown to markedly inhibit platelet reactivity and thrombosis ${ }^{38}$.

\section{Leaky gut and low-grade endotoxemia}

A number of studies have shown that low-grade endotoxemia due to leaky gut is present in human subjects under certain conditions and that, in animal models, such low-grade endotoxemia has pro-inflammatory effects and enhances atherosclerosis ${ }^{39,40}$.

\section{Senescence-associated cellular secretory phenotype and} inflammation

Senescent cells are characterized by short telomeres and other markers such as senescence-associated beta-glycosidase (SABeta Gal) p53, p21, and p16 $6^{\text {ink4a41 }}$. Experimental studies in murine models have shown the accumulation of senescent endothelial cells, macrophages, and smooth muscle cells in atherosclerotic plaques ${ }^{42}$. Senescent cells express inflammatory cytokines in early stages of murine atherosclerosis and matrix-degrading enzymes in more advanced stages of atherosclerosis; both of these are implicated in atherogenesis and plaque instability ${ }^{32}$. Depletion of these senescent cells reduces atherosclerosis and creates a more stable plaque composition, suggesting a causal 
role for senescent cells in inflammation, atherosclerosis, and plaque instability ${ }^{41}$. These observations suggest that senolytic compounds, such as fisetin, that remove senescent cells may have athero-protective effects ${ }^{42}$. Another important situation dealing with senescence and inflammation is chronic kidney disease. Uremia is typified by activation of innate immunity, which is characterized by activated monocytes and increased synthesis of pro-inflammatory cytokines (IL-6, tumor necrosis factor, and IL-1 $)^{43-45}$. In mice, chronic inflammation is related to cellular senescence, and senescent cells may upregulate and secrete pro-inflammatory cytokines as part of a senescence-associated secretory phenotype ${ }^{46}$. This scenario is associated with progressive atherosclerosis and vascular calcification ${ }^{45}$.

\section{Somatic hematopoetic mutations and inflammation}

Aging is associated with accumulation of somatic hematopoetic mutations in certain genes that contribute to increased risk of hematological cancers and also to increased cardiovascular mortality ${ }^{47,48}$. This phenomenon is also called clonal hematopoetic mutations of indeterminate potential (CHIP). Mutations in DNMT3A or TET2 genes, in particular, are associated with enhanced cardiovascular events ${ }^{47,48}$. Experimental observations in a murine model have demonstrated that enhanced atherosclerosis with TET2 mutations is likely due to increased activity of NLRP3 inflammasome in monocytes ${ }^{47,48}$. Such age-dependent somatic mutations may contribute to increased inflammation and cardiovascular risk in the elderly.

\section{Impaired anti-inflammatory mechanisms}

Acute inflammation generally resolves with time through the activity of a number of inflammation-resolving cellular and molecular mechanisms. These inflammation-resolving mechanisms involve lipid-derived pro-resolving humoral factors and cellular mechanisms. One of these cellular mechanisms involves clearance of apoptotic debris (efferocytosis) by macrophages mediated by several cellular receptors such as MerTK $^{49-51}$. Thus, chronic persistent and smoldering inflammation may also result from failure of inflammation-resolving mechanisms in the host ${ }^{49-51}$. Molecules like CD47 that present a "don't eat me" signal to the cells that clear apoptotic debris have been shown to be expressed in murine and human atherosclerotic plaques, and inhibition of CD47 stimulates efferocytosis and reduces atherosclerosis in murine models ${ }^{50}$. Humoral mediators such as resolvins, protectins, and maresins are also involved in resolution of inflammation ${ }^{49}$. Chronic inflammation likely results from an imbalance between pro-inflammatory and anti-inflammatory mediators; however, precise factors that modulate this delicate balance are poorly understood.

\section{Acute and chronic mental stress and inflammation}

Mental stress is known to play an adverse role in cardiovascular disease, but the mechanisms linking stress to atherosclerosis have remained elusive. Recent studies on mice have shown that acute and chronic mental stress induce a pro-inflammatory response in which the brain sends signals to the bone marrow and spleen, stimulating hematopoiesis and production of pro-inflammatory monocytes $\left(\mathrm{Ly}^{\mathrm{hi}}\right)^{\text {) that are recruited into athero- }}$ sclerotic plaques, creating enhanced plaque inflammation ${ }^{52,53}$.
Human studies have also provided support for the link between mental stress, inflammation, and atherosclerotic artery disease $\mathrm{e}^{54-58}$. Interestingly, meditation has also been shown to reduce inflammatory markers and cardiovascular risk ${ }^{56}$.

\section{Sleep deprivation and fragmentation, inflammation, and atherosclerosis}

Sleep fragmentation or deprivation is associated with increased cardiovascular risk in human subjects ${ }^{59,60}$. Recent experimental studies in murine models have shown that sleep fragmentation enhances atherosclerosis by suppressing the release of hypocretin (orexin) from the hypothalamus; suppression of hypocretin results in increased myeloid hematopoiesis and production of pro-inflammatory monocytes, likely by stimulating the release of CSF-1 by pre-neutrophilic precursors in the bone marrow $^{61}$. Non-invasive imaging has shown an increased subclinical atherosclerotic burden in subjects with inadequate or fragmented sleep ${ }^{62}$. Obstructive sleep apnea (OSA) is recognized as an independent risk factor for atherosclerotic cardiovascular disease ${ }^{63,64}$. In patients with OSA, pro-inflammatory molecules, such as soluble intercellular adhesion molecule 1, soluble vascular adhesion molecule 1 , and MCP-1, were detected at very high levels with direct correlation to the desaturation index $^{63,64}$. A study with a rat model of recurrent obstructive apneas reported increased leukocyte-endothelial cell interactions characterized by a significant increase in the flux of leukocyte rolling, number of rolling leukocytes, and number of adherent leukocytes ${ }^{65}$.

\section{Summary and perspective}

A large body of experimental and clinical observations highlights the role of inflammation in atherosclerosis and its complications (that is, plaque disruption and thrombosis). Some part of this inflammation is mediated through unhealthy lifestyles and conventional risk factors that can be addressed with aggressive lifestyle and risk factor modification. However, further incremental risk reduction may require agents that directly target inflammation. In keeping with these, a number of drugs targeting inflammation were tested in the clinic. The results, with the exception of those of the Canakinumab Anti-inflammatory Thrombosis Outcome Study (CANTOS), have largely been disappointing. Phospholipase inhibitors darapladib and varespladib, targeting pro-inflammatory phospholipases, failed to reduce cardiovascular events in randomized trials ${ }^{66,67}$. A mitogen-activated protein kinase inhibitor, losmapimod, also failed to reduce cardiovascular events ${ }^{68}$. Because there appear to be multiple and redundant pathways for inflammation in athero-thrombosis, identification of the precise and optimal target for modification is relatively challenging. Recently, low-dose methotrexate was tested in the CIRT (cardiovascular inflammation reduction trial) and shown not to reduce cardiovascular events in high-risk patients ${ }^{69}$. Interestingly, in this trial, low-dose Methotrexate also failed to reduce circulating inflammatory markers high-sensitivity C-reactive protein (hs-CRP) and IL-6 ${ }^{69}$. In contrast, methotrexate has been shown to reduce inflammatory markers when used in the setting of high inflammatory burden ${ }^{7,8,70}$. On the other hand, preliminary studies of cardiovascular benefits of low-dose colchicine have been encouraging, 
and large-scale randomized clinical trials examining the cardiovascular benefits of low-dose colchicine are ongoing ${ }^{71}$. A recent significant development in this arena was the landmark CANTOS trial, in which canakinumab, a monoclonal antibody to IL-1 $\beta$, showed significant cardiovascular benefit without changes in circulating lipids, albeit at the expense of an increase in fatal infections ${ }^{72}$. High cost, increased risk of serious infection, and a relatively modest clinical benefit with canakinumab will make it unfeasible for routine clinical use.

It is clear that the search for agents that selectively target adverse vascular inflammation without interfering with beneficial aspects of inflammation must continue $22,34,35$. Several promising avenues of research, including different strategies, are in active development. Among these are the blockage of CD40induced tumor necrosis factor receptor-associated factor (TRAF) signaling in macrophages ${ }^{73}$ and triggering receptor expressed on myeloid cells 1 (TREM- 1$)^{74}$, strategies that activate the inhibitory immune receptor $\mathrm{CD} 31^{75}$, or blocking CD47/SIRPA (signal regulatory protein alpha) signaling to promote inflammation resolution in plaques through enhanced efferocytosis ${ }^{50}$.
The CANTOS and CIRT trials showed important limitations related to immunosuppression. On the other hand, phospholipase inhibitors failed in reducing cardiovascular events. The optimal targets for modulation of inflammation need to be identified in order to develop anti-inflammatory therapies with high efficacy and safety. A potential and hopeful approach is the favorable modulation of atherosclerosis by vaccination by using antigens relevant to atherosclerosis. This would involve the development of antigen-specific antibodies or induction of antigen-specific Treg cells or other athero-protective immune responses. However, identification of the antigenic epitopes most relevant for atherosclerotic disease development in humans and some difficulties in vaccine design (for example, choice of the adjuvant, safety, and stability) are obstacles that will need to be overcome.

\section{Grant information}

The author(s) declared that no grants were involved in supporting this work.
1. Libby P, Loscalzo J, Ridker PM, et al.: Inflammation, Immunity, and Infection in Atherothrombosis: JACC Review Topic of the Week. J Am Coll Cardiol. 2018; 72(17): 2071-81.

PubMed Abstract | Publisher Full Text | Free Full Text

2. Falk E, Shah PK, Fuster V: Coronary plaque disruption. Circulation. 1995; 92(3): 657-71.

PubMed Abstract | Publisher Full Text

3. F Partida RA, Libby $P$, Crea $F$, et al.: Plaque erosion: a new in vivo diagnosis and a potential major shift in the management of patients with acute coronary syndromes. Eur Heart J. 2018; 39(22): 2070-6.

PubMed Abstract | Publisher Full Text | Free Full Text | F1000 Recommendation

4. Shah PK: Molecular mechanisms of plaque instability. Curr Opin Lipidol. 2007; 18(5): 492-9.

PubMed Abstract | Publisher Full Text

5. Pothineni NVK, Subramany S, Kuriakose K, et al.: Infections, atherosclerosis, and coronary heart disease. Eur Heart J. 2017; 38(43): 3195-201.

PubMed Abstract | Publisher Full Text

6. Ahearn J, Shields KJ, Liu CC, et al:: Cardiovascular disease biomarkers across autoimmune diseases. Clin Immunol. 2015; 161(1): 59-63. PubMed Abstract | Publisher Full Text

7. Westlake SL, Colebatch AN, Baird J, et al: The effect of methotrexate on cardiovascular disease in patients with rheumatoid arthritis: a systematic literature review. Rheumatology (Oxford). 2010; 49(2): 295-307. PubMed Abstract | Publisher Full Text

8. Micha R, Imamura F, Wyler von Ballmoos M, et al.: Systematic Review and Meta-Analysis of Methotrexate Use and Risk of Cardiovascular Disease. Am J Cardiol. 2011; 108(9): 1362-70.

PubMed Abstract | Publisher Full Text | Free Full Text

9. Skålén K, Gustafsson M, Rydberg EK, et al:: Subendothelial retention of atherogenic lipoproteins in early atherosclerosis. Nature. 2002; 417(6890): 750-4.

PubMed Abstract | Publisher Full Text

10. F Ference BA, Ginsberg HN, Graham I, et al.: Low-density lipoproteins cause atherosclerotic cardiovascular disease. 1. Evidence from genetic, epidemiologic, and clinical studies. A consensus statement from the European Atherosclerosis Society Consensus Panel. Eur Heart J. 2017; 38(32): 2459-72. PubMed Abstract | Publisher Full Text | Free Full Text | F1000 Recommendation

11. Virchow R: Cellular pathology. John Churchill, London 1858. Reference Source

12. Ait-Oufella $\mathrm{H}$, Taleb $\mathrm{S}$, Mallat $\mathrm{Z}$, et al:: Recent advances on the role of cytokines in atherosclerosis. Arterioscler Thromb Vasc Biol. 2011; 31(5): 969-79.

PubMed Abstract | Publisher Full Text
13. Shah PK: Jekyll and Hyde of HDL: a lipoprotein with a split personality. Eur Heart J. 2013; 34(46): 3531-4.

PubMed Abstract | Publisher Full Text

14. Lee-Rueckert M, Kovanen PT: The mast cell as a pluripotent HDL-modifying effector in atherogenesis: from in vitro to in vivo significance. Curr Opin Lipidol. 2015; 26(5): 362-8.

PubMed Abstract | Publisher Full Text

15. Nguyen SD, Maaninka K, Lappalainen J, et al:: Carboxyl-Terminal Cleavage of Apolipoprotein A-I by Human Mast Cell Chymase Impairs Its Anti-Inflammatory Properties. Arterioscler Thromb Vasc Biol. 2016; 36(2): 274-84. PubMed Abstract | Publisher Full Text | Free Full Text

16. Dai G, Kaazempur-Mofrad MR, Natarajan S, et al:: Distinct endothelial phenotypes evoked by arterial waveforms derived from atherosclerosis-susceptible and -resistant regions of human vasculature. Proc Natl Acad Sci U S A. 2004; 101 14871-6.

Publisher Full Text

17. F Jongstra-Bilen J, Haidari M, Zhu SN, et al.: Low-grade chronic inflammation in regions of the normal mouse arterial intima predisposed to atherosclerosis. J Exp Med. 2006; 203(9): 2073-83.

PubMed Abstract | Publisher Full Text | Free Full Text | F1000 Recommendation

18. $\mathrm{F}$ Duewell $\mathrm{P}, \mathrm{Kono} \mathrm{H}$, Rayner $\mathrm{KJ}$, et al.: NLRP3 inflammasomes are required for atherogenesis and activated by cholesterol crystals. Nature. 2010; 464(7293): 1357-61.

PubMed Abstract | Publisher Full Text | Free Full Text | F1000 Recommendation

19. F Warnatsch A, loannou M, Wang Q, et al.: Inflammation. Neutrophil extracellular traps license macrophages for cytokine production in atherosclerosis. Science. 2015; 349(6245): 316-20.

PubMed Abstract | Publisher Full Text | Free Full Text | F1000 Recommendation

20. F Grebe A, Hoss F, Latz E: NLRP3 Inflammasome and the IL-1 Pathway in Atherosclerosis. Circ Res. 2018; 122(12): 1722-1740.

PubMed Abstract | Publisher Full Text | F1000 Recommendation

21. Rajamäki K, Lappalainen J, Oörni K, et al.: Cholesterol crystals activate the NLRP3 inflammasome in human macrophages: a novel link between cholesterol metabolism and inflammation. PLoS One. 2010; 5(7): e11765. PubMed Abstract | Publisher Full Text | Free Full Text

22. Onat UI, Yildirim AD, Tufanli Ö, et al.: Intercepting the Lipid-Induced Integrated Stress Response Reduces Atherosclerosis. J Am Coll Cardiol. 2019; 73(10): 1149- 69.

PubMed Abstract | Publisher Full Text | Free Full Text

23. F Coll RC, Robertson AA, Chae JJ, et al:: A small-molecule inhibitor of the NLRP3 inflammasome for the treatment of inflammatory diseases. Nat Med. 
2015; 21(3): 248-55.

PubMed Abstract | Publisher Full Text | Free Full Text | F1000 Recommendation

24. F Weisberg SP, McCann D, Desai M, et al:: Obesity is associated with macrophage accumulation in adipose tissue. J Clin Invest. 2003; 112(12): 1796-808.

PubMed Abstract | Publisher Full Text | Free Full Text | F1000 Recommendation

25. Rocha VZ, Folco EJ, Sukhova G, et al:: Interferon-gamma, a Th1 cytokine, regulates fat inflammation: a role for adaptive immunity in obesity. Circ Res. 2008; 103(5): 467-76.

PubMed Abstract | Publisher Full Text | Free Full Text

26. Rocha VZ, Folco EJ, Ozdemir C, et al.: CXCR3 controls T-cell accumulation in fat inflammation. Arterioscler Thromb Vasc Biol. 2014; 34(7): 1374- 81 PubMed Abstract | Publisher Full Text | Free Full Text

27. Donath MY, Shoelson SE: Type 2 diabetes as an inflammatory disease. Nat Rev Immunol. 2011; 11(2): 98-107.

PubMed Abstract | Publisher Full Text

28. Shah PK: Innate immune pathway links obesity to insulin resistance. Circ Res. 2007; 100(11): 1531-3.

PubMed Abstract | Publisher Full Text

29. F Lüscher TF: Inflammation: the new cardiovascular risk factor. Eur Heart J. 2018; 39(38): 3483-7.

PubMed Abstract | Publisher Full Text | F1000 Recommendation

30. Lietz M, Berges A, Lebrun S, et al:: Cigarette-smoke-induced atherogenic lipid profiles in plasma and vascular tissue of apolipoprotein E-deficient mice are attenuated by smoking cessation. Atherosclerosis. 2013; 229(1): 86-93. PubMed Abstract | Publisher Full Text

31. F Niemann B, Rohrbach S, Miller MR, et al.: Oxidative Stress and Cardiovascular Risk: Obesity, Diabetes, Smoking, and Pollution: Part 3 of a 3-Part Series. J Am Coll Cardiol. 2017; 70(2): 230-51.

PubMed Abstract | Publisher Full Text | Free Full Text | F1000 Recommendation

32. Miller MR, Shaw CA, Langrish JP. From particles to patients: Oxidative stress and the cardiovascular effects of air pollution. Future Cardiol. 2012; 8(4): 577-602. PubMed Abstract | Publisher Full Text

33. Wenzel U, Turner JE, Krebs C, et al.: Immune Mechanisms in Arteria Hypertension. J Am Soc Nephrol. 2016; 27(3): 677-86. PubMed Abstract | Publisher Full Text | Free Full Text

34. Chyu KY, Shah PK: In Pursuit of an Atherosclerosis Vaccine. Circ Res. 2018; 123(10): 1121-3.

PubMed Abstract | Publisher Full Text

35. Shah PK, Chyu KY, Dimayuga PC, et al.: Vaccine for atherosclerosis. J Am Coll Cardiol. 2014; 64(25): 2779-91.

PubMed Abstract | Publisher Full Text

36. F Kearns A, Gordon J, Burdo TH, et al:: HIV-1-Associated Atherosclerosis: Unraveling the Missing Link. J Am Coll Cardiol. 2017; 69(25): 3084-98. PubMed Abstract | Publisher Full Text | Free Full Text | F1000 Recommendation

37. Chen S, Shimada K, Crother TR, et al:: Chlamydia and Lipids Engage a Common Signaling Pathway That Promotes Atherogenesis. J Am Coll Cardiol. 2018; 71(14): 1553-70

PubMed Abstract | Publisher Full Text | Free Full Text

38. F Brown JM, Hazen SL: Microbial modulation of cardiovascular disease. Nat Rev Microbiol. 2018; 16(3): 171-81.

PubMed Abstract | Publisher Full Text | Free Full Text | F1000 Recommendation

39. Wiesner P, Choi SH, Almazan F, et al:: Low doses of lipopolysaccharide and minimally oxidized low-density lipoprotein cooperatively activate macrophages via nuclear factor kappa B and activator protein-1: Possible mechanism for acceleration of atherosclerosis by subclinical endotoxemia. Circ Res. 2010; 107(1): 56-65.

PubMed Abstract | Publisher Full Text | Free Full Text

40. Stoll LL, Denning GM, Weintraub NL, et al.: Potential Role of Endotoxin as a Proinflammatory Mediator of Atherosclerosis. Arterioscler Thromb Vasc Biol. 2004; 24(12): 2227-36.

PubMed Abstract | Publisher Full Text

41. F Childs BG, Baker DJ, Wijshake $\mathrm{T}$, et al:: Senescent intimal foam cells are deleterious at all stages of atherosclerosis. Science. 2016; 354(6311): 472-7. PubMed Abstract | Publisher Full Text | Free Full Text | F1000 Recommendation

42. F Yousefzadeh MJ, Zhu Y, McGowan SJ, et al.: Fisetin is a senotherapeutic that extends health and lifespan. EBioMedicine. 2018; 36: 18-28. PubMed Abstract | Publisher Full Text | Free Full Text | F1000 Recommendation

43. F Jurk D, Wilson C, Passos JF, et al.: Chronic inflammation induces telomere dysfunction and accelerates ageing in mice. Nat Commun. 2014; 2: 4172. PubMed Abstract | Publisher Full Text | Free Full Text | F1000 Recommendation

44. Kato $\mathrm{S}, \mathrm{Chmielewski} \mathrm{M,} \mathrm{Honda} \mathrm{H}$, et al.: Aspects of immune dysfunction in endstage renal disease. Clin J Am Soc Nephrol. 2008; 3(5): 1526-33. PubMed Abstract | Publisher Full Text | Free Full Text

45. Kooman JP, Kotanko $\mathrm{P}$, Schols $\mathrm{AM}$, et al: Chronic kidney disease and premature ageing. Nat Rev Nephrol. 2014; 10(12): 732-42. PubMed Abstract | Publisher Full Text

46. Campisi J, d'Adda di Fagagna F: Cellular senescence: when bad things happen to good cells. Nat Rev Mol Cell Biol. 2007; 8(9): 729-40.

PubMed Abstract | Publisher Full Text
47. F Libby P, Ebert BL: CHIP (Clonal Hematopoiesis of Indeterminate Potential). Circulation. 2018; 138(7): 666-8. PubMed Abstract | Publisher Full Text | Free Full Text | F1000 Recommendation

48. F Ebert BL, Libby P: Clonal Hematopoiesis Confers Predisposition to Both Cardiovascular Disease and Cancer: A Newly Recognized Link Between Two Major Killers. Ann Intern Med. 2018; 169(2): 116-7.

PubMed Abstract | Publisher Full Text | F1000 Recommendation

49. $\mathrm{F}$ Kasikara $\mathrm{C}$, Doran $\mathrm{AC}$, Cai $\mathrm{B}$, et al.: The role of non-resolving inflammation in atherosclerosis. J Clin Invest. 2018; 128(7): 2713-23.

PubMed Abstract | Publisher Full Text | Free Full Text | F1000 Recommendation

50. F Kojima Y, Volkmer JP, McKenna K, et al:: CD47-blocking antibodies restore phagocytosis and prevent atherosclerosis. Nature. 2016; 536(7614): 86-90. PubMed Abstract | Publisher Full Text | Free Full Text | F1000 Recommendation

51. F Bäck M, Yurdagul A Jr, Tabas I, et al.: Inflammation and its resolution in atherosclerosis: mediators and therapeutic opportunities Nat Rev Cardiol. 2019; 16(7): 389-406.

PubMed Abstract | Publisher Full Text | F1000 Recommendation

52. $\mathrm{F}$ Dutta $\mathrm{P}$, Courties $\mathrm{G}$, Wei $\mathrm{Y}$, et al:: Myocardial infarction accelerates atherosclerosis. Nature. 2012; 487(7407): 325-9. PubMed Abstract | Publisher Full Text | Free Full Text | F1000 Recommendation

53. Heidt T, Sager HB, Courties G, et al:: Chronic variable stress activates hematopoietic stem cells. Nat Med. 2014; 20(7): 754-8. PubMed Abstract | Publisher Full Text | Free Full Text

54. Han Y, Jing J, Tu S, et al.: ST elevation acute myocardial infarction accelerates non-culprit coronary lesion atherosclerosis. Int J Cardiovasc Imaging. 2014; 30(2): 253-61.

PubMed Abstract | Publisher Full Text

55. Joshi NV, Toor I, Shah ASV, et al:: Systemic Atherosclerotic Inflammation Following Acute Myocardial Infarction: Myocardial Infarction Begets Myocardial Infarction. J Am Heart Assoc. 2015; 4(9): e001956. PubMed Abstract | Publisher Full Text | Free Full Text

56. F Levine GN, Lange RA, Bairey-Merz CN, et al:: Meditation and Cardiovascular Risk Reduction: A Scientific Statement From the American Heart Association. J Am Heart Assoc. 2017; 6(10): pii: e002218.

PubMed Abstract | Publisher Full Text | Free Full Text | F1000 Recommendation

57. Hamer M, Kivimaki M, Lahiri A, et al:: Persistent cognitive depressive symptoms are associated with coronary artery calcification. Atherosclerosis. 2010; 210(1): are ass

209-13.

58. $\mathrm{F}$ Hamer M, O'Donnell K, Lahiri A, et al.: Salivary cortisol responses to mental stress are associated with coronary artery calcification in healthy men and women. Eur Heart J. 2010; 31(4): 424-9.

PubMed Abstract | Publisher Full Text | F1000 Recommendation

59. Hublin C, Partinen M, Koskenvuo M, et al.: Sleep and Mortality: A PopulationBased 22-Year Follow-Up Study. Sleep. 2007; 30(10): 1245-53. PubMed Abstract | Publisher Full Text | Free Full Text

60. Cappuccio FP, Cooper D, D'Elia L, et al.: Sleep duration predicts cardiovascula outcomes: A systematic review and meta-analysis of prospective studies. Eur Heart J. 2011; 32(12): 1484-92.

PubMed Abstract | Publisher Full Tex

61. F McAlpine CS, Kiss MG, Rattik S, et al.: Sleep modulates haematopoiesis and protects against atherosclerosis. Nature. 2019; 566(7744): 383-387. PubMed Abstract | Publisher Full Text | Free Full Text | F1000 Recommendation

62. F Domínguez F, Fuster V, Fernández-Alvira JM, et al:: Association of Sleep Duration and Quality With Subclinical Atherosclerosis. J Am Coll Cardiol. 2019; 73(2): 134-44

PubMed Abstract | Publisher Full Text | F1000 Recommendation

63. Song D, Fang G, Greenberg $\mathrm{H}$, et al:: Chronic intermittent hypoxia exposureinduced atherosclerosis: A brief review. Immunol Res. 2015; 63(1-3): 121-30. PubMed Abstract | Publisher Full Text

64. Lévy P, Pépin JL, Arnaud C, et al:: Obstructive sleep apnea and atherosclerosis. Prog Cardiovasc Dis. 2009; 51(5): 400-10. PubMed Abstract | Publisher Full Text

65. Nácher M, Serrano-Mollar A, Farré R, et al.: Recurrent obstructive apneas trigge early systemic inflammation in a rat model of sleep apnea. Respir Physiol Neurobiol. 2007; 155(1): 93-6.

PubMed Abstract | Publisher Full Tex

66. F O'Donoghue ML, Braunwald E, White HD, et al:: Effect of darapladib on major coronary events after an acute coronary syndrome: the SOLID-TIMI 52 randomized clinical trial. JAMA. 2014; 312(10): 1006-15. PubMed Abstract | Publisher Full Text | F1000 Recommendation

67. Nicholls SJ, Kastelein JJ, Schwartz GG, et al:: Varespladib and cardiovascula events in patients with an acute coronary syndrome: the VISTA-16 randomized clinical trial. JAMA. 2014; 311(3): 252-62. PubMed Abstract | Publisher Full Text

68. F O'Donoghue ML, Glaser R, Cavender MA, et al.: Effect of Losmapimod on Cardiovascular Outcomes in Patients Hospitalized With Acute Myocardial Infarction: A Randomized Clinical Trial. JAMA. 2016; 315(15): 1591-9. PubMed Abstract | Publisher Full Text | F1000 Recommendation 
69. F Ridker PM, Everett BM, Pradhan A, et al: Low-Dose Methotrexate for the Prevention of Atherosclerotic Events. N Engl J Med. 2019; 380(8): 752-62. PubMed Abstract | Publisher Full Text | Free Full Text | F1000 Recommendation

70. Choi HK, Hernán MA, Seeger JD, et al:: Methotrexate and mortality in patients with rheumatoid arthritis: a prospective study. Lancet. 2002; 359(9313): 1173-7. PubMed Abstract | Publisher Full Text

71. F Nidorf SM, Thompson PL: Why Colchicine Should Be Considered for Secondary Prevention of Atherosclerosis: An Overview. Clin Ther. 2019; 41(1): 41-8. PubMed Abstract | Publisher Full Text | F1000 Recommendation

72. F Ridker PM, Everett BM, Thuren T, et al:: Antiinflammatory Therapy with Canakinumab for Atherosclerotic Disease. N Engl J Med. 2017; 377(12): 1119-31. PubMed Abstract | Publisher Full Text | F1000 Recommendation
73. F Seijkens TTP, van Tiel CM, Kusters PJH, et al:: Targeting CD40-Induced TRAF6 Signaling in Macrophages Reduces Atherosclerosis. J Am Coll Cardio. 2018; 71(5): 527-42.

PubMed Abstract | Publisher Full Text | Free Full Text | F1000 Recommendation

74. F Joffre J, Potteaux S, Zeboudj L, et al:: Genetic and Pharmacological Inhibition of TREM-1 Limits the Development of Experimental Atherosclerosis. J Am Coll Cardiol. 2016; 68(25): 2776-93.

PubMed Abstract | Publisher Full Text | F1000 Recommendation

75. Groyer E, Nicoletti A, Ait-Oufella $\mathrm{H}$, et al:: Atheroprotective effect of CD31 receptor globulin through enrichment of circulating regulatory T-cells. J Am Coll Cardiol. 2007; 50(4): 344-50.

PubMed Abstract | Publisher Full Text 


\section{Open Peer Review}

\section{Current Peer Review Status:}

\section{Editorial Note on the Review Process}

Faculty Reviews are review articles written by the prestigious Members of Faculty Opinions. The articles are commissioned and peer reviewed before publication to ensure that the final, published version is comprehensive and accessible. The reviewers who approved the final version are listed with their names and affiliations.

\section{The reviewers who approved this article are:}

\section{Version 1}

\section{Magnus Bäck}

Division of Valvular and Coronary Disease, Karolinska University Hospital, Stockholm, Sweden

Competing Interests: No competing interests were disclosed.

\section{Petri T Kovanen}

Atherosclerosis Research Laboratory, Wihuri Research Institute, Helsinki, Finland

Competing Interests: No competing interests were disclosed.

\section{Avijit Lahiri}

British Cardiac Research Trust, Prince Albert Road, London, NW8 7RE, UK

Competing Interests: No competing interests were disclosed.

\section{Jan Nilsson}

Department of Clinical Sciences Malmö, Lund University, Lund, Sweden

Competing Interests: No competing interests were disclosed.

The benefits of publishing with F1000Research:

- Your article is published within days, with no editorial bias

- You can publish traditional articles, null/negative results, case reports, data notes and more

- The peer review process is transparent and collaborative

- Your article is indexed in PubMed after passing peer review

- Dedicated customer support at every stage

For pre-submission enquiries, contact research@f1000.com 